\title{
Arborescences
}

Revue d'études françaises

\section{At the Interface between Sociolinguistic and Grammatical Development: The Expression of Futurity in L2 French} A Preliminary Study

\section{Martin Howard}

Numéro 5, juillet 2015

Acquisition du français L2

URI : https://id.erudit.org/iderudit/1032664ar

DOI : https://doi.org/10.7202/1032664ar

Aller au sommaire du numéro

\section{Éditeur(s)}

Département d'études françaises, Université de Toronto

ISSN

1925-5357 (numérique)

Découvrir la revue

Citer cet article

Howard, M. (2015). At the Interface between Sociolinguistic and Grammatical Development: The Expression of Futurity in L2 French: A Preliminary Study. Arborescences, (5), 97-125. https://doi.org/10.7202/1032664ar

\section{Résumé de l'article}

À titre d'exemple de la variation socio-grammaticale en français langue-cible, la variation morphologique dans l'expression du futur constitue un domaine intéressant pour lier le développement grammatical et sociolinguistique de l'apprenant L2. Cette entité conceptuelle est encore plus intéressante puisque des études antérieures de cette variable en français langue maternelle indiquent une certaine divergence entre les normes prescriptive et sociolinguistique dans le choix qu'a le locuteur entre la forme fléchie et la forme périphrastique ou même l'utilisation du présent pour marquer le futur : les restrictions sémantiques sur l'utilisation de chaque forme mises de l'avant par l'approche prescriptive ne semblent pas tenir pour l'usage de la langue réelle. Le présent article s'intéresse au défi acquisitionnel que présente le choix entre les trois formes pour l'apprenant L2, en s'appuyant sur une analyse quantitative d'apprenants irlandais du français en salle de classe et en immersion. Comme des études antérieures d'autres variables (voir, par exemple, Dewaele 2004 ; Mougeon et al. 2010), nos résultats indiquent un effet important de l'exposition naturaliste aux normes des locuteurs natifs quant à l'expression du futur, d'une part, et de la variété de la langue-cible à laquelle les apprenants sont exposés, d'autre part.
Tous droits réservés @ Département d'études françaises, Université de Toronto, 2015
Ce document est protégé par la loi sur le droit d'auteur. L’utilisation des services d’Érudit (y compris la reproduction) est assujettie à sa politique d'utilisation que vous pouvez consulter en ligne.

https://apropos.erudit.org/fr/usagers/politique-dutilisation/ 


\section{SOMMAIRE}

Jeffrey Steele et Mihaela Pirvulescu. Université de Toronto Introduction

Jean-Marc Dewaele. University of London

07 Gender Errors in French Interlanguage: The Effect of Initial Consonant versus Initial Vowel of the Head Noun

Emily Felker, Annie Tremblay et Peter Golato. Université d'Utrecht, Université du Kansas et Université d'État du Texas Traitement de l'accord dans la parole continue chez les apprenants anglophones tardifs du français

Caitlin Gaffney. Université de Toronto L'acquisition L2 des compléments infinitifs français par des apprenants anglophones

Martin Howard. University College Cork

97 At the Interface between Sociolinguistic and Grammatical Development: The Expression of Futurity in L2 French - A Preliminary Study

Alain Thomas. Université de Guelph Nous/on : de la réalité linguistique à la salle de classe 


\title{
At the Interface between Sociolinguistic and Grammatical Development: The Expression of Futurity in L2 French
}

\author{
A Preliminary Study
}

Martin Howard. University College Cork

\begin{abstract}
As an example of socio-grammatical variation in target language French, the morphological variation at work in the expression of futurity constitutes an interesting area to intricately relate the L2 learner's sociolinguistic and grammatical development. This conceptual entity is all the more interesting since previous studies of this variable in native speaker French point to a certain discrepancy between prescriptive and sociolinguistic norms in the speaker's choice between the inflected and periphrastic forms as well as in the use of the present to mark futurity, whereby the prescriptively hypothesized semantic restrictions on the use of each form are not seen to be upheld in real language usage. This paper is concerned with the acquisition challenge that such a threefold choice poses to the L2 learner of French, based on a quantitative cross-sectional analysis of Irish instructed and study abroad learners of French. Reflecting previous studies of other variables (see, for example, Dewaele 2004; Mougeon et al. 2010), results suggest an important effect for naturalistic exposure on the acquisition of native speaker norms surrounding the expression of futurity, as well as for the actual target language variety to which the learners are exposed.
\end{abstract}

The expression of futurity in target language French offers an interesting area of study in L2 acquisition, given that the L2 development of the morphological means used to express futurity illuminates not solely the learner's grammatical development, but also his/her sociolinguistic development in appropriating the native speaker's variation patterns underlying the use of such means in French (see Dewaele 2004; Mougeon et al. 2010; Howard et al. 2013). In terms of the difficulty that the expression of futurity poses, the learner is therefore faced with a twofold challenge. On the one hand, as outlined below, from the perspective of the learner's grammatical development, future reference is less characterised by one formone function symmetry than by form-function asymmetry which is more characteristic of the multiple morphological forms available in target language French, and whose variable use overlaps in the functional contexts within which they prescriptively occur. 
On the other hand, such variable use of the morphological forms available for future reference has been shown to be not just conceptualised as a feature of the native speaker's grammatical repertoire, but also as an important feature of the speaker's sociolinguistic competence. The acquisition challenge for the learner is therefore twofold, as (s)he is also confronted with the problem of learning the sociolinguistic values underlying the actual use of each form in target language French, which may differ from the semantic values which prescriptive norms have assigned to them within a grammatical framework.

\section{The Expression of Futurity in Target Language}

While English also uses the present progressive in future time contexts, French has three morphological forms which express futurity, namely the present, an inflected form, and a periphrastic device involving aller 'to go' as exemplified in (1)-(3):

(1) Je pars demain

I leave.pREs tomorrow

'I leave tomorrow.'

(2) Je partirai demain

I leave. Fut tomorrow

'I will leave tomorrow.'

(3) Je vais partir demain

I go.pres leave. INF tomorrow

'I'm going to leave tomorrow.'

Such forms have historically been the focus of various prescriptive rules which generally suggest that the choice of each form differentially reflects "the degree of speaker interest, engagement and certainty vis-à-vis the (future) eventuality" (Poplack and Turpin 1999: 135). For example, use of the periphrastic future is seen to imply greater certainty as well as immediacy in relation to the temporal occurrence of the event. In contrast, while use of the inflected form implies opposite values, namely a lesser degree of certainty and immediacy such that the occurrence of the event is projected much further into the future, use of the present is deemed to be more akin to the periphrastic form whereby certainty and immediacy are values that both forms seem to share (for discussion of such differential values, see, for example, Gougenheim 1971; Fleischman 1982; Sundell 1991; Vet 1993; Confais 1993, 1995). 
However, a number of empirical studies point to the contrast which exists between such prescriptive rules and everyday speech, whereby in some varieties of French the inflected and present forms are observed to be minimally used compared to their periphrastic equivalent. For example, in a study of francophone speakers in Canada's National Capital Region, Poplack and Turpin (1999) report respective levels of use at 20\%, $73 \%$, and $7 \%$ for the inflected, periphrastic, and present forms respectively, such that the authors suggest that the inflected form has been subject to gradual loss in a long process of language change. In particular, use of the periphrastic form is more dominant among younger speakers, whereas the inflected form is used more frequently among older speakers. Other Canadian studies which also report dominant use of the periphrastic form compared to the inflected form include Deshaies and Laforge (1981) for Quebec City, as well as Emirkanian and Sankoff (1985) and Zimmer (1994) for Montreal. However, Blondeau's (2006) relatively more recent study in Montreal points to the complexity of characterizing the inflected form as one undergoing gradual loss. Her longitudinal findings for the same speakers over a period of 24 years reveal how they increasingly use the inflected form as they age, such that at the third stage of the study (24 years after the initial data elicitation), they make greater use of the inflected form than they did when they were in their late teens and early twenties. Blondeau interprets such findings in terms of an effect for prestige placed on use of standard linguistic norms by the linguistic market.

A further study of the same database by Evans Wagner and Sankoff (2011) offers complementary insights to Blondeau's findings. In a longitudinal analysis of the same Montreal speaker cohort at two data collection times over a twelve-year period between 1971 and 1984, these authors also report increased use of the inflected future at the second data collection time, as well as higher levels of use of this form among their older speaker-participants compared to the younger speakers at the first data collection time. The authors interpret such findings in the context of the general consensus that the variation between the inflected and periphrastic future forms reflects a long process of language change. In contrast, they suggest a strong effect for stable age-grading, whereby an apparent time analysis which might point to such language change is premature in the context of the findings of their real time analysis. Since the inflected future is used with much greater frequency among older speakers in the earlier dataset compared to the younger speakers, such differences are much less acute in the second dataset, where the younger speakers, now older, use the inflected future more frequently than they had done previously. Indeed, it is noteworthy that some of the younger speakers did not use it at all as young adults, in contrast with their use of this form twelve years later, suggesting that it is a form that becomes part of their grammar at a later age.

Beyond mere levels of usage, studies also document a range of contextual features which impinge on the use of each form in spoken 
language, but which prescriptive grammars have not previously highlighted. For example, while Poplack and Turpin (1999) find that the periphrastic future is used in all semantic contexts, the inflected form is generally restricted to more formal speech, and to co-occurring with negative utterances, formulaic chunks, and the formal $2^{\text {nd }}$ person address pronoun, vous. In contrast, the present is found to co-occur mostly with temporal adverbs. Zimmer (1994), however, finds that some syntactic contexts where the inflected form is favoured, namely in the context of negation, are subject to increasing usage of the periphrastic form. All in all, the findings detailed point to a discrepancy with prescriptive norms such that semantic restrictions underlying such norms are not in evidence in real language usage. The periphrastic form is by far the dominant form used across all contexts. Even when the other forms are used, their use is not found to be semantically restricted to specific contexts. Rather, all three forms overlap in the semantic contexts in which they occur, with only the present showing a slight tendency to mark events whose likelihood of occurrence is more immediate.

While Poplack and Turpin's study is exemplary in terms of the insights it provides into their informants' grammar in relation to future time reference, empirical studies of continental French in a similar vein are generally restricted to issues related to levels of use of the inflected and periphrastic forms, and tend not to account for the present. On this score, they tend to offer opposing findings to those for Quebecois and Ontarian French, but which have also been observed in the case of Acadian French varieties. For example, Jeanjean (1988) finds that the inflected and periphrastic forms are used in almost equal proportions among her speakers in Aix-en-Provence, at 58\% and 42\% respectively, although the author does caution that such high frequency of use of the inflected future may reflect an effect of discourse type in her study, carried out by the Groupe aixois de recherche en syntaxe (GARS). ${ }^{1}$ In an overview study of various literary corpora, Sundell (1991) also suggests tendencies of usage in the same direction, reporting that use of the periphrastic form accounts for about 1 in 3 future time expressions compared to the inflected form which accounts for 2 in 3 . Roberts (2012) offers a more recent study of a metropolitan speech corpus with speakers from different areas of France. His findings point to a reversal in the relative frequency of each form compared to those presented in earlier metropolitan studies, with a rate of $58.8 \%$ for the periphrastic future and $41.2 \%$ for the inflected future. Similarly, in the case of Acadian French, King and Nadasdi (2003) find that use of the inflected future generally dominates over the periphrastic form at 53\% and $47 \%$ respectively, although Chevalier (1996) offers opposing findings, showing that the periphrastic form is by far

${ }^{1}$ See also Blanche-Benveniste (1990) for discussion of the findings in relation to futurity as well as for a presentation of the GARS' work on the spoken French language. 
the more dominant form, just as in Quebecois and Franco-Ontarian varieties. $^{2}$

In view of such differential findings concerning the process of language change which seems to be impinging on use of the inflected form to differing extents in continental and Franco-Canadian contexts, as well as the discrepancy between prescriptive norms and real language usage in a FrancoCanadian context at least, the question arises as to how the L2 learner in general, and the instructed L2 learner in particular, will express futurity in his/her language usage, and in so doing, come to reflect either prescriptive grammatical norms or native speaker sociolinguistic norms.

\section{The L2 Acquisition of Futurity}

In terms of previous research, the acquisition of futurity has received some attention in recent years, complementing earlier research since the 1980s which has very fruitfully illuminated the acquisition of temporality in general, with particular reference to present and past time, as well as progressivity (see Bardovi-Harlig (2000) and Dietrich et al. (1995) for an overview, as well as Salaberry and Shirai (2002) and Li and Shirai (2000) for state-of-the-art studies). Such pivotal work has very succinctly documented the difficulty that the acquisition of temporality poses for the learner, with the emergence of aspectuo-temporal morphology characterized by a long and difficult trajectory, even after many years of learning. In relation to futurity, existing studies suggest that its grammatical marking is acquired late, such that the various morphological forms do not emerge simultaneously and may be only minimally used even by quite advanced learners. For example, in the case of L2 Italian, Giacalone Ramat (1992) places the inflectional form towards the latter end of the acquisition order that she presents for her naturalistic learners in the Pavia Project. Wiberg (2002) also offers an insightful study of the marking of futurity in L2 Italian. Her findings suggest that learners often avoid speaking about the future by presenting future events in terms of more habitual actions. While this is also a feature of native speaker discourse, Wiberg suggests that tense-switching between future and habitual events gives rise to much more tightly-structured discourse in the case of her native speaker informants compared to the learners.

In the case of L2 English, Bardovi-Harlig (2002, 2004a, 2004b, 2005) offers further insightful findings in a number of related studies. Notable findings include the fact that will is the most frequent form in her

${ }^{2}$ Such differential findings for Acadian and Quebec French reflect other features of French which, while in decline in Quebec, seem to be retained in Acadia (for discussion, see King and Nadasdi 2003). 
learners' interlanguage: perhaps due to its structural simplicity, the form is highly frequent even when past time forms have not yet stabilized, while also being used in tandem with a wide range of overtly modal verbs expressing future "possibility, probability, intention and desire or volition (Bybee, 1985) of which intentionality is the most common" (Bardovi-Harlig 2004b: 1). ${ }^{3}$ In contrast to such frequent recourse to will and lexical future verbs, other forms are much less frequent. They include the go future, as well as present and progressive forms. In particular, when it does emerge, the go future is often restricted to formulaic chunks, before more creative usage is observed. Even then, it tends to be first used to express intentions, only being extended to predictions at a later stage (see Bardovi-Harlig 2004a).

While investigations of other L2s are limited to a few important studies, curiously, the expression of futurity has been the subject of very little work in the case of L2 French, and this in spite of its specific appeal as a double-guised area of study involving both grammatical and sociolinguistic developmental issues. In general, studies such as Bartning (1997), Harley (1992), Kihlstedt (1998), and Labeau (2005) have simply noted the limited use of the inflected future, such that it would seem to be acquired late, without revealing how acquisition of that specific form relates to other markers of futurity. Notable exceptions, however, are Ayoun (2013) and Nadasdi et al. (2003). Ayoun's study focuses on North American university learners using data from a written composition and cloze test. In comparison with a native speaker control group who overwhelmingly used the inflected future, the learners used the same form to a lesser extent, with much less frequent use of the present futurate and the periphrastic future. In the cloze test which the author notes required use of the inflected future in a majority of cases, the learners demonstrated much greater variation in use of the forms with different predicates, compared to the native speakers who tended to favour the inflected future, but also evidenced some variation. A strong proficiency effect was noted with increased use of the inflected future at more advanced levels.

Nadasdi et al.'s (2003) study explores the expression of futurity as a feature of their Canadian immersion learners' sociolinguistic competence. While not reaching Franco-Canadian native speaker levels of use of $70 \%$, the periphrastic form constitutes the more dominant form in their learners' expression of futurity, with the inflected and simple present forms being used much less frequently. The learners therefore very much reflect native speaker norms whereby the periphrastic future is the dominant marker of futurity, with much lower use of the inflected form. Beyond such a sociolinguistic study, Moses (2002) offers more developmental insights, suggesting that the simple future is acquired late compared to the earlier emergence of the

${ }^{3}$ Examples of such verbs include want to and hope to. 
periphrastic future in his American learners. Such a developmental pattern is in line with Schlyter's (1990) findings for her Swedish naturalistic learners.

While such studies have provided pivotal insights into the expression of futurity, the study to be presented here aims to complement them by exploring a number of further questions, as outlined in the following.

\section{Presentation of the Study}

In this section, we first present the aims of the study undertaken. Thereafter, we outline the methodology in relation to the participants, data collection, and analysis.

\subsection{Aims}

As mentioned at the outset, future time reference constitutes an interesting area in which to consider the relationship between the L2 learner's grammatical and sociolinguistic development: the question of how grammatical development in this area may reflect sociolinguistic norms is an important one. While Nadasdi et al. (2003) explore use of future time forms in a Canadian immersion context, there is scope to complement such a study in a European context, where the sociolinguistic norms surrounding future time reference are not necessarily the same as those in the Canadian francophone context. For example, as alluded to earlier, use of the periphrastic future is generally seen to be higher in some Canadian French varieties compared to metropolitan French, where the inflected future is seen to be stronger. By presenting findings for learners in a European context, the study we present therefore provides some insights into how different local speech norms may impact differentially on their acquisition by the L2 learner, such that Nadasdi et al.'s findings may be more or less specific to the Canadian immersion context.

Related to such a question of generalisation, or not, of findings across speech communities, is the issue of how learning context also has an impact. For example, whereas Nadasdi et al. focus on Canadian immersion learners, we also aim to explore how naturalistic exposure, on the one hand, and classroom instruction, on the other, may differentially impact the learner's expression of futurity. Of particular interest here is the potential impact of the discrepancy we have already alluded to between the prescriptive norms underlying future time reference and the sociolinguistic norms of real language usage. While prescriptive grammars choose to assign different semantic values to each future time form, real language use suggests considerable overlap in their usage, particularly in the case of the periphrastic form. The question therefore arises as to how naturalistic and instructed 
learners may differentially reflect prescriptive and sociolinguistic norms depending on their context of learning, where such norms may be available to greater or lesser extents. For example, it is to be expected that the classroom learner has greater exposure to prescriptive norms than in the case of the naturalistic learner.

\subsection{Learner-Participants}

The study is based on a quantitative analysis of the speech of 18 Irish Anglophone learners of French. At the time of the study, the learnerparticipants, who were aged between 20-22 years, and were studying French and one other subject as part of their university studies. They had been learning French for two to three years at university, and previously for five to six years at high school. They had also learnt Irish for thirteen to fourteen years in an instructed setting; some had also learnt other languages, notably German and Spanish, also through classroom instruction. As prescribed in the Irish Modern Languages curriculum, their exposure to French was based on a communicative method during their pre-university schooling where they followed four 40-minute classes per week. That is not to say, however, that they received no formal grammar instruction. They did through formal written language classes at university, where they engaged in a range of grammar, translation, and other written language activities. Such classes were twice-weekly one-hour sessions, and complemented by a weekly one-hour oral language class conducted by a native metropolitan speaker. They also had considerable exposure to the target language through the use of various text types, notably of a literary and journalistic nature, but also in the spoken medium. As specialist students in French, they also followed a range of courses in French literature and culture.

In terms of their learner profile, the learners reflect the linguistic and extralinguistic characteristics of the advanced instructed learner variety described by Bartning (1997; 2009). For example, at a linguistic level, the target language morpho-syntactic forms can generally be considered as less emerging than having emerged in the learners' language system. However, use of such morphology by the learners is characterised by significant linguistic variation whereby they do not engage in categorical use of the appropriate morpho-syntactic forms in contexts where these would be deemed to be required, but rather use the appropriate form in alternation with one or more other less appropriate ones, giving rise to significant variation in their usage. This variation is particularly evident, for example, in the case of tense-aspectmodality marking, gender attribution and agreement, as well as marking of number and person. Such variation contrasts with the learners' metalinguistic knowledge of such morphology which has been developed over many years through their formal study of French grammar, and which contrasts with 
naturalistic learners' more implicit exposure to the language. Bartning also notes such extensive instruction as a key characteristic of the advanced instructed learner variety in contrast with naturalistic learners. A further characteristic at an extralinguistic level concerns the advanced learner's motivation, whereby (s)he is seen as evidencing high motivation insofar as (s)he has chosen to specialise in the L2 at university level for the purposes of his/her studies. Such motivation is also often evident in the advanced instructed learner's choice to spend a period of residence in the target language community as part of an exchange program within his/her university studies.

In the case of our learner-participants, some had spent such a period of residence in France. This involved an academic year at a French university as part of a European inter-university exchange program, where they followed an agreed program of study in collaboration with their home university. Their courses were primarily in French literature and translation taken with their native French counterparts, although they did not receive any formal instruction in the French language. While in France, the learners lived in the French university halls of residence, offering further opportunities for naturalistic interaction with their French student counterparts. While not wholly naturalistic learners, such individuals constitute a pseudo-naturalistic group for the purposes of the 'naturalistic versus instructed' comparison underlying this study. This group of learners contrasts with the other learners in our study who had not studied abroad, and who did not therefore have such naturalistic exposure. We divided these latter learners into two groups depending on the year in which they were studying, namely second year or third year. The learners who had completed two years of university study form Group 1, while the study abroad learners constitute Group 2 since they had also completed two years of study, after which they spent a year in France; the learners who had completed three years of study without going to France constitute Group 3. In sum, taking Group 1 as the baseline group, the grouping of the learners allows for a comparison of the impact of naturalistic exposure (Group 2) relative to further classroom instruction (Group 3). Table 1 summarises the distinguishing characteristics of each group in terms of their exposure to French. Each group consisted of six learners, which, while small, was compensated in some way by our attempts to elicit an ample amount of speech data from each learner. We outline the data collection method in the following. 


\begin{tabular}{|cccc|}
\hline Group & $\begin{array}{c}\text { High school French } \\
\text { instruction (Years) }\end{array}$ & $\begin{array}{c}\text { University French } \\
\text { instruction (Years) }\end{array}$ & $\begin{array}{c}\text { Study abroad } \\
\text { in France (Years) }\end{array}$ \\
\hline Group 1 & 6 & 2 & - \\
Group 2 & 6 & 2 & 1 \\
Group 3 & 6 & 3 & - \\
\hline
\end{tabular}

Table 1: The learner-groups

\subsection{Data Elicitation}

For the purposes of a large-scale project on the acquisition of French, the learner-participants volunteered to participate in individual sociolinguistic interviews with the researcher who demonstrated near-native competence in the target language. The interviews were conducted in a university office and lasted about one hour, giving rise to over 18 hours of spoken data. The word count of each interview ranged from 5,787 to 8,716 words. The interviews followed the guidelines proposed by Labov (1984) for the elicitation of natural, spontaneous speech. These guidelines principally centred around Labov's network of conversational modules which we adapted as a function of the general interests of our informants. These included, among others, pastimes and vacations, education, career, and future life plans. Following their elicitation, the data were transcribed into standard orthography with the aid of the transcription conventions presented in Blanche-Benveniste and Jeanjean (1987). The study of futurity presented here is one of many for which the data have been used in the study of the advanced learner's grammatical and sociolinguistic development (for previous studies, see, for example, Howard 2005, 2006a, 2006b).

\subsection{Data Analysis}

We extracted all verb tokens used in future time contexts, where, in Reichenbachian terms, the event time is clearly posterior to the speech time. Important indicators of such future time reference were the use of temporal adverbs and adverbials, as well as the temporal frame provided by the learner's interlocutor in which (s)he was called upon to temporally anchor his/her response. For example, such a future time-frame was clearly evident in the interviewer's questions about the interviewee's plans for the future in terms of employment, vacations, and future studies. Following previous studies such as Poplack and Turpin (1999), Evans Wagner and Sankoff (2011), and Roberts (2012), we were careful to exclude future time forms which did not express 
future time reference but rather carried other values, such as habituality and movement, as exemplified respectively in (4) and (5) from the learner data:

(4) de temps en temps on va regarder un film ensemble (Learner 1, Group 2)

from time to time we go.PRES watch.INF a film together 'From time to time we go watch a movie together.'

(5) je vais passer chez mes amis (Learner 4, Group 2)

I go.pres pass.INF by my friends

'I'm going to call on my friends.'

The tokens abstracted from the data were subsequently coded for their morphological form and the actual lexical verb concerned as well as a number of factors believed to impact their variable usage, as previously investigated in native speaker discourse by Poplack and Turpin (1999), Evans Wagner and Sankoff (2011), and Roberts (2012). They included:

- The presence/absence of temporal adverbs and adverbials and their specification depending on whether their temporal sense was specific or not. Such a factor is interesting from a functionalist perspective since it allows us to consider how functional constraints may impinge on whether the learners choose to mark futurity morphologically or not - the functionalist hypothesis would suggest that such marking is less likely when the meaning of futurity is otherwise available in context such as through the use of a temporal adverb.

Specific

(6a) Je pars demain (Learner 3, Group 1)

I leave.pres tomorrow

'I'm leaving tomorrow.'

$\underline{\text { Non-specific }}$

(6b) J'irai en Australie un jour (Learner 5, Group 1)

I go.fut in Australia a day

'I will go to Australia some day.'

- Temporal distance between the event and speech time - proximal, where the event is situated as occurring within a few days of the speech time, and distal, where its occurrence is situated beyond a number of days. The cutoff time was less than one week. Such a factor allows us to consider how the learners' choice of future time marker is semantically constrained as 
predicted by prescriptive grammars which traditionally suggest that the inflected form is restricted to distal contexts in contrast to the present and the periphrastic form which are used to mark proximity, giving rise to a greater sense of immediacy and certainty regarding the likelihood of occurrence of the event.

\section{$\underline{\text { Proximal }}$}

(7a) Je pars demain (Learner 3, Group 1) I leave. pres tomorrow 'I'm leaving tomorrow.'

$\underline{\text { Distal }}$

(7b) Je vais faire du travail bénévole pendant l'été (Learner 6, Group 2)

I go.PRES do.INF some work voluntary during the summer 'I'm going to do volunteer work during the summer.'

- Contingency of the event where the validity of the assertion differs in its relative hypothetical value, with contingent events being hypothetical in terms of their likelihood of occurrence, and assumed events reflecting a certainty. Contingent events were therefore identified in the case of events that were dependent on another event expressed as a condition with si if. In contrast, assumed events were identified in cases where no such condition was present, but rather the event was presented as a certainty. Once again, such a factor reflects the semantic issue at play in prescriptive grammars whereby the present and the periphrastic forms would be expected to mark events whose likelihood of occurrence is greater than in the case of less certain events which are expected to be marked with the inflected form.

\section{Contingent}

(8a) Si j'étudie beaucoup, je ferai l'examen (Learner 2, Group 3) If I study.pres a lot, I do.fut the exam 'If I study a lot, I will do the exam.'

Assumed

(8b) Puisque j'ai raté l'examen une fois, je devrai travailler beaucoup (Learner 4, Group 2)

Since I have fail.PAST PART the exam one time, I have to.FuT work. INF a lot 
'Since I've failed the exam once, I will have to work a lot.'

- Negation polarity in terms of whether the assertion of the future event was negated or not. Poplack and Turpin (1999) find this factor to exert an extremely strong effect on their speakers' use of the inflected future form, in contrast with affirmative statements which show a strong probability to produce the periphrastic future.

\section{$\underline{\text { Affirmative }}$}

(9a) Je vais faire une maitrise après ma licence (Learner 2, Group 2) I go.FuT do.INF a masters after my degree 'I'm going to do a masters after my degree.'

\section{$\underline{\text { Negative }}$}

(9b) Je ne suis pas sûr que j'enseignerai le français (Learner 5, Group 1)

$I_{\text {NEG }}$ am NEG sure that I teach.FUT the French

'I'm not sure that I will teach French.'

- Subject form of the verb to be marked, where Poplack and Turpin (1999) find the inflected future form to frequently co-occur with the formal vous subject form, reflecting the more formal status of the inflected form. However, regrettably, the data did not provide enough tokens of different subject forms in future time contexts, in particular the vous form, and therefore the issue of the role of subject form was excluded here from the subsequent analysis.

While some previous native speaker studies have investigated a potential effect for the factor of imminence, they did not find an effect whereby a specific form might be favoured to mark impending as opposed to non-impending events. Since such a factor was previously found not to be at play in native speaker studies, we did not include the factor here. A final factor concerns a potential priming effect, whereby the choice of morphological form used in the interviewer's questions about the future may have impacted the learner's choice of form. While the issue of priming is beyond the scope of this paper (for discussion of priming in SLA research, see McDonough and Trofimovich 2009), the potential effect of priming was minimised on a number counts. In particular, we note that the interviews were conducted by the same experimenter, and that the use of the different future time forms by the experimenter was relatively similar across the interviews with the individual learners. Indeed, an essential principle in conducting a sociolinguistic interview within the Labovian framework, is that 
the interviewer prepare the questions in advance, and that similar questions are asked of all interviewees. Moreover, it is crucial that the interviewer be completely at ease with the questions, so that they can be naturally integrated during the course of the interview being conducted. Against such a background, the different groups of learners nonetheless varied in their use of the different future time markers, as will be outlined in the results to be presented below. We also note that the learners established a future timeframe as they developed their discourse without the interviewer necessarily doing so. In other words, the learners produced the future time forms at various stages in their discourse in contexts where a future timeframe had not necessarily been established by the interviewer in his questions, making the issue of priming particularly complex to explore, and also to control for in the study presented here.

\section{Results}

In total, we identified 116 verb tokens where the underlying meaning of futurity displayed the variation under focus here. The number of tokens is very limited, especially given the size of our database relative to the number of learners in the study, and points to the potential limits of eliciting future time contexts in natural spoken data. As noted earlier, the data were elicited through the Labovian sociolinguistic interview which has proven particularly useful for the elicitation of naturally occurring speech features. However, in the case of future time reference in learner language at least, it may be the case that other data collection methods such as cloze tests would be more fruitful for tapping into the learner's grammar for the expression of futurity, and which allow the researcher to manipulate the linguistic factors believed to underlie future time reference in a more controlled way. Notwithstanding, the benefit of using the sociolinguistic interview is that it allows us to illuminate the use of future time morphology in the learner's natural, spontaneous speech which constitutes a very different task to other data collection methods which tap into the learner's metalinguistic knowledge and comprehension. In terms of comparison, it is interesting to note that some native speaker studies also exemplify the difficulty of eliciting future time forms. For example, Roberts' (2012) study based on Beeching's corpus of metropolitan French (see Beeching 2002), identifies a total of 434 tokens of the inflected and periphrastic future for the entire speech sample elicited from 95 interviews, giving an average of 4.56 tokens of both forms per interview. Indeed, the participants in our study here produced an average of 6.44 tokens (including the present futurate), suggesting that the problem of frequency in the elicitation of future time contexts may not be specific to L2 speakers but may also be at play with native speakers. While the issue of frequency is problematic given that the number of contexts of certain speech features is 
not highly abundant, it does not necessarily preclude a preliminary analysis which is our intention here. Indeed, some authors such as Carruthers (1999) acknowledge such a problem of frequency in the study of rare forms as an issue with which sociolinguistic methods have to grapple, and where consensus on the matter remains an issue. As a very preliminary study, with a limited number of participants and tokens of the variable, we forego statistical analysis which is not feasible given the sample size. Nonetheless, we note that the trends outlined are true at an individual level across the learners within each group.

Table 2 outlines the distribution of the three markers of futurity in such contexts across the learners according to their level of instruction and whether they had spent a prolonged period (one year) in the target language community. As we noted previously, Group 3 had completed an extra year of instruction compared to Groups 1 and 2, while Group 2 had returned from a year in France, but had received the same level of instruction as the learners in Group 1. Apart from tokens of the three forms under study, we also found tokens of other forms in future time contexts, which we categorise in Table 2 as 'other'. These primarily concerned barbarisms, and other non-future forms, such as the conditional, as illustrated in the following examples.

(10) les étudiants partis aux États-Unis cet été (Learner 1, Group 1) the students leave.PAST PART to the United States this summer 'The students will go to the US this summer.'

(11) l'examen il serait difficile (Learner 4, Group 3) the exam it be.cond difficult 'The exam would be difficult.'

\begin{tabular}{|cccccc|}
\hline \multirow{2}{*}{ Group } & \multirow{2}{*}{$\begin{array}{c}\text { Total } \\
\text { contexts (n) }\end{array}$} & Present & $\begin{array}{c}\text { Inflected } \\
\text { future }\end{array}$ & $\begin{array}{c}\text { Periphrastic } \\
\text { form }\end{array}$ & Other \\
\hline Group 1 & 28 & 61 & 28 & 0 & 11 \\
Group 2 & 26 & 27 & 38 & 31 & 4 \\
Group 3 & 62 & 32 & 47 & 8 & 13 \\
\hline
\end{tabular}

Table 2: Distribution of morphological forms in future time contexts

Table 2 reveals a number of interesting trends. Firstly, we note that in Group 1, the present form dominates in future time contexts to a much greater extent than the inflected form, reflecting the frequently observed use of the former marker in past time contexts in learner language in general (see, for example, Dietrich et al. 1995; Bardovi-Harlig 2000). Given such frequency of the present to mark not only past time but also future time among the learners in Group 1, it may constitute in many ways a passe- 
partout form used in all temporal contexts. In the case of the other groups, while the present is used to a lesser extent compared to Group 1, we do not find that its use reflects a tendency observed by Wiberg (2002) for singular events expected to occur in the future to be presented as habitual events situated in the present. Rather, when it is used by these groups, the present seems to express a general truth surrounding the event, although we find no evidence to then make the corresponding claim that events marked with the inflected and periphrastic forms are in some way lacking in a truth value, as exemplified in the following:

(12a) Je fais mes examens en mai (Learner 5, Group 2)

I do.pres my exams in May

'I'm doing my exams in May.'

(12b) Je vais faire mes examens en mai (Learner 4, Group 2)

I go.fuT do.INF my exams in May

'I'm doing my exams in May.'

Apart from the present, it is also noteworthy that the periphrastic form is not used at all by Group 1, in spite of its formal similarity with its English equivalent. In contrast, the learners in Group 3 use the latter form, but they do so to a minimal extent, with the inflected form constituting a far more dominant form for the expression of futurity in their interlanguage. Indeed, compared to Group 1, the further classroom instruction that they have received seems to have increased their use of the inflected form, such that they demonstrate more reduced use of the present compared to Group 1. It is also noteworthy that Group 3 produces the largest number of future time contexts overall, such that they spoke about the future to a greater extent than the other groups. Notwithstanding such differences between the number of tokens produced by Group 3 in relation to the other groups future, it does not necessarily point to a specific advantage for this group. We note in particular that all the interviews were very informal, and that the interviewer adhered to the principle of tangential shifting, allowing the learnerinterviewee to lead the direction of the conversation when (s)he took such a lead, as well as to develop their response as (s)he so wished. While the learners in Group 3 talked more about the future than the learners in the other groups, such a difference may simply reflect natural differences in the development and direction of the conversation across the groups.

In the case of Group 2, these study abroad learners behave similarly to Group 3 in terms of their more reduced use of the present, but unlike the other groups, they demonstrate far greater use of the periphrastic future, reflecting the native speaker findings we previously presented. Indeed, when we exclude the present form, and consider only the inflected and periphrastic forms, we find that Group 2 uses the two latter forms at rates of 56\% and 
$44 \%$ respectively, very similar to rates of use among native speakers as reported by Jeanjean (1988). However, compared to Roberts' (2012) more recent findings, the frequency of use of the periphrastic future (44\%) is somewhat lower in Group 2 (Roberts reports a rate of use of 59\%), while their use of the inflected future $(56 \%)$ is higher (Roberts reports a rate of use of $41 \%$ ). In contrast, the learners in Group 3 differ considerably from these metropolitan native speaker studies. Again, when we exclude the present from the figures presented in Table 2, we find that Group 3 uses the inflected form at the far higher rate of $85 \%$ compared to the periphrastic form whose relative use in contrast only reaches $15 \%$. Indeed, such levels of use of the inflected and periphrastic forms by Group 3 reflect those reported by Wales (2002) for journalistic discourse, where the author reports respective rates of $90 \%$ and $10 \%$ use of these forms in the French regional newspaper, Ouest France.

Such high use of the inflected form by the classroom learners in Group 3 reflects a general tendency for classroom learners to overuse formal sociolinguistic variants at the expense of more informal ones, where the inflected future is considered to constitute a more formal variant compared to its more informal equivalent of the periphrastic future. In contrast, the more frequent use of the periphrastic form among the study abroad learners (Group 2), compared to their Group 1 and 3 peers, reflects a similar tendency observed in the literature for the beneficial effect of naturalistic exposure on the acquisition of such informal sociolinguistic variants (see Rehner et al. 2003; Dewaele 2004; Howard 2006b; Mougeon et al. 2010; and Howard et al. 2013, for discussion of use of sociolinguistic variants by classroom and immersion learners, and of the role of naturalistic exposure in the acquisition of sociolinguistic variation).

The frequent use of the inflected form in Group 3 is also reflected in the more extensive lexical range of verbs to which this form is extended by this group, at 16 verbs in total, compared to just 5 and 7 verbs for Groups 1 and 2 respectively (see the Appendix). Thus, while making less use of the inflected form, Group 1 extends this form to an almost similar range of verbs as Group 2. We do not find any difference for regular and irregular verbs, such that irregularly inflected forms might emerge before regularly inflected ones, as reported by Bayley (1996) and Dietrich et al. (1995) for the acquisition of past time morphology (see also Wolfram's 1985 Principle of Perceptual Salience which suggests that the saliency surrounding irregular morphology favours its earlier acquisition compared to regular morphological forms). In the case of the periphrastic form, we also note that, in spite of its differential use across the groups, both Groups 2 and 3 extend this form to a very limited range of lexical verbs, at just 4 and 2 respectively.

In spite of such differences among the groups, reflecting an important effect for classroom instruction in the emergence of the inflected form, as well as for naturalistic exposure in bringing about use of the periphrastic form, it is 
also noteworthy that our learners do not reflect the findings for learners in a Canadian immersion context reported in Nadasdi et al. (2003). While not reaching the native speaker level of $70 \%$ use reported by Poplack and Turpin, the periphrastic form constitutes the more dominant form in their learners' expression of futurity. As we have seen, our study abroad learners use the periphrastic future at a rate of $31 \%$. In particular, such differences between our study abroad learners and the Canadian immersion learners suggest a potential effect for the variety of the target language to which the learners are exposed. In summary, while naturalistic exposure has considerably facilitated the acquisition of the periphrastic form by our study abroad learners, classroom instruction has not, with the inflected form dominating to differing degrees among our more advanced classroom learners, whether they have studied abroad (Group 2) or not (Group 1).

Apart from the distributional use of each form, we also considered how use of each form may be (dis)favoured when other hypothesized conditioning factors are present in context, as previously described. A number of patterns will be discussed reflecting the impact of the linguistic context on the learners' choice of future marker. Since Group 1 does not use the periphrastic form and makes less use of the inflected form, we will detail such patterns in the following for Groups 2 and 3, only referring to Group 1 where relevant (data for this latter group will nonetheless be provided in the tables); failure to find tokens of some contextual features in the data for Group 1 also makes it necessary to focus on Groups 2 and 3. In the case of subject form, as we noted previously, the range of possible subject forms in future time contexts other than the 1st person singular form was not sufficient for analysis.

The first factor to be considered is that of temporal distance, results for which are presented in Table 3.

\begin{tabular}{|cccccc|}
\hline \multirow{2}{*}{ Group } & $\begin{array}{c}\text { Temporal } \\
\text { distance }\end{array}$ & Present & $\begin{array}{c}\text { Inflected } \\
\text { future }\end{array}$ & $\begin{array}{c}\text { Periphrastic } \\
\text { future }\end{array}$ & Total (n) \\
\cline { 3 - 5 } Group 1 & $\begin{array}{c}\text { Distal } \\
\text { Proximal }\end{array}$ & 68 & 32 & & 25 \\
\hline \multirow{2}{*}{ Group 2 } & $\begin{array}{c}\text { Distal } \\
\text { Proximal }\end{array}$ & 26 & 44 & 30 & 23 \\
\hline \multirow{2}{*}{ Group 3 } & Distal & 30 & & 50 & 2 \\
\hline & Proximal & 57 & 70 & & 40 \\
& & & 7 & 36 & 14 \\
\hline
\end{tabular}

Table 3: Temporal distance: Occurrence of future forms in distal and proximal contexts

For Groups 2 and 3, we note that the inflected form tends to occur in distal contexts, while the present and periphrastic forms are more common in proximal contexts, reflecting what might be expected from prescriptive 
norms. In the case of Group 2, the inflected future is not found at all in proximal contexts and just one token is produced by Group 3. Similarly, the periphrastic form is not produced at all in distal contexts by the learners in Group 3. However, it is nonetheless noteworthy that such semantic restrictions are relative, since all three forms occur across both context types.

Table 4 presents the results for the factor of temporal adverbs. Since the number of non-specific adverbs was very limited, we combined this category with that of specific adverbs to form a single category 'Adverbs'.

\begin{tabular}{|cccccc|}
\hline \multirow{2}{*}{ Group } & $\begin{array}{c}\text { Temporal } \\
\text { adverb }\end{array}$ & Present & $\begin{array}{c}\text { Inflected } \\
\text { future }\end{array}$ & $\begin{array}{c}\text { Periphrastic } \\
\text { future }\end{array}$ & Total (n) \\
\cline { 3 - 5 } Group 1 & None & 86 & 14 & & 14 \\
& Adverb & 46 & 54 & & 11 \\
\hline \multirow{2}{*}{ Group 2 } & None & 13 & 40 & 47 & 15 \\
& Adverb & 50 & 40 & 10 & 10 \\
\hline \multirow{2}{*}{ Group 3 } & None & 38 & 51 & 11 & 47 \\
& Adverb & 29 & 71 & & 7 \\
\hline
\end{tabular}

Table 4: Temporal adverbs: Occurrence of future forms when temporal adverbs are presentlabsent in context

In the case of temporal adverbs, it is more difficult to identify common patterns across the groups. At best, we can simply observe that, with Group 2, the present is more frequent when a temporal adverb is present, whereas the periphrastic form is more frequent when there is no adverb, reflecting what might be expected in terms of the functionalist hypothesis. The inflected form does not show any specific pattern. In the case of Group 3 , use of the inflected future is slightly higher when an adverb is present, whereas use of the present is slightly higher when there is no adverb (same tendency for Group 1). However, caution is needed in considering such a pattern given the overall very small number of tokens of future forms that cooccur with temporal adverbs. In Group 1, the pattern of use is in contrast to the predictions of the functionalist hypothesis, with use of the present being much greater when temporal adverbs are absent, while the inflected form is more frequent when they are present. However, since the present dominates overall in this group's future time contexts, there is need for caution in concluding that there might be a genuine effect for the temporal adverbs in this group.

The difficulty in identifying a common effect found with temporal adverbs is also observed in the case of some of the other factors. The results for the factor of contingency are presented in Table 5. Here, while the inflected form is clearly preferred by Group 2 in contingent contexts, the number of tokens is extremely small, at just two. Group 3 tends to use the present in such contexts, with the inflected form tending to occur in assumed 
contexts. Again, however, caution is needed given that the learners in Group 3 only produce four tokens of contingent contexts. Assumed contexts do not show any preference for a specific form in Group 2.

\begin{tabular}{|cccccc|}
\hline \multirow{2}{*}{ Group } & Contingency & \multicolumn{3}{c}{ Form (\% of tokens) } & \multirow{2}{*}{ Total (n) } \\
\cline { 3 - 5 } & Present & $\begin{array}{c}\text { Inflected } \\
\text { future }\end{array}$ & $\begin{array}{c}\text { Periphrastic } \\
\text { future }\end{array}$ & \\
\hline \multirow{2}{*}{ Group 1 } & Contingent & 100 & & & 4 \\
& Assumed & 62 & 38 & & 21 \\
\hline \multirow{2}{*}{ Group 2 } & Contingent & & 100 & 35 & 23 \\
\hline \multirow{2}{*}{ Group 3 } & Assumed & 30 & 35 & & 4 \\
& Contingent & 75 & 25 & 10 & 49 \\
\hline
\end{tabular}

\section{Table 5: Contingency: Occurrence of future forms in contingent and assumed contexts}

Table 6 presents the results in the case of the factor of polarity. We find that the inflected form tends to occur more frequently in affirmative contexts in both Groups 2 and 3. Negative contexts, in contrast, involve greater use of the periphrastic form in Group 2 and of the present in Group 3.

\begin{tabular}{|cccccc|}
\hline \multirow{2}{*}{ Group } & Polarity & Present & $\begin{array}{c}\text { Inflected } \\
\text { future }\end{array}$ & $\begin{array}{c}\text { Periphrastic } \\
\text { future }\end{array}$ & Total (n) \\
\cline { 3 - 5 } & Affirmative & 71 & 29 & & 24 \\
\multirow{2}{*}{ Group 1 } & Negative & & 100 & & 1 \\
\hline \multirow{2}{*}{ Group 2 } & Affirmative & 39 & 50 & 11 & 18 \\
& Negative & & 14 & 84 & 7 \\
\hline \multirow{2}{*}{ Group 3 } & Affirmative & 30 & 60 & 9 & 43 \\
& Negative & 64 & 27 & 9 & 11 \\
\hline
\end{tabular}

Table 6: Polarity: Occurrence of future forms in affirmative and negative statements

\section{Discussion}

Explicitly concerned with the expression of futurity in L2 French, this area has provided a number of key-themes which have been at the heart of this preliminary investigation, namely the impact of learning context on the acquisition of socio-grammatical variation in the area of future reference, and secondly the role of prescriptive grammatical norms versus sociolinguistic norms in such acquisition. We will discuss the results from both perspectives, which are ultimately inter-related.

\section{Arborescences}


With regard to use of the three forms marking future reference in target language French, a first point to note is the difficulty that the use of the periphrastic form seems to pose to our instructed learners. We have already seen that the use of this form is not evident among the learners in Group 1, while it is used to a limited extent among the learners in Group 3. In contrast, the present is the more dominant form in Group 1, while Group 3 demonstrates greater use of the inflected form, although the use of the present still occurs. Group 3 also makes some use of the periphrastic form, although not to the same extent as the study abroad learners in Group 2 who also demonstrate considerable use of the inflected form. Such findings indicate an important role for learning context, with naturalistic exposure impacting considerably the use of both the inflected and periphrastic forms, while the further classroom instruction received by the learners in Group 3 has similarly led to considerable use of the inflected form, but much less so in the case of the periphrastic form. In terms of the gradual use of such forms, a hierarchical order can therefore be proposed as follows for the expression of futurity: present $>$ inflected form $>$ periphrastic form.

Such an order, however, is at odds with previous findings. For example, Schlyter (1990) and Moses (2002) suggest that the periphrastic form is acquired earlier than the inflected form, while Nadasdi et al. (2003) report that the periphrastic form is the more dominant form among their Canadian immersion learners. Similarly, Harley (1992) notes that, structurally, the periphrastic form should not pose great difficulty to Anglophone learners of French given its structural similarity to the periphrastic form in English. Furthermore, the order is contra what might be expected given native speaker patterns of use, where the use of the periphrastic form is more dominant than, if not similar to, the inflected form. The order also goes against a more general tendency for the L2 learner to prefer analytical structures to synthetic ones, whereby it would have been expected that the inflected form would pose greater difficulty to the learners than the periphrastic form. However, in contrast with French, the inflected future's equivalent in the learners' L1, namely will, is found to dominate compared to the periphrastic equivalent of going to (Poplack and Turpin 1999: 162). Given that English was also generally the L1 of Nadasdi et al.'s (2003) Canadian immersion learners, it would seem that the difference in results between our two studies may be assigned to the fact that our learners have been influenced by pedagogical norms which put the emphasis on the inflected form as the 'true' marker of futurity ${ }^{4}-$ the present and periphrastic

${ }^{4}$ We use the term 'pedagogical norm' in a general sense to refer to linguistic forms favoured during L2 instruction, but which may not necessarily reflect the variation that is present in native speaker usage, and which emphasize the perceived standard norm as opposed to other more informal ones. For example, while Nadasdi et al. (2003) find that the inflected future is favoured in textbooks, the periphrastic future dominates in the teacher input to which their 
forms tend not to receive the same pedagogic attention in terms of their functional values in the expression of futurity. The fact that the present is frequently used among our learners in Group 1, but is subsequently greatly reduced in level of use in the other groups, would suggest that its future value may be somewhat different from how this form is used in native speaker French. That is to say, it may be used simply as a default marker of futurity by less proficient learners, until the other forms are acquired, unlike its true future value in native speaker French where it is used interchangeably with the other future forms. It only begins to assume the guise of a native-like variable marker, rather than an interlingual default marker, when the inflected form emerges as the more dominant marker of futurity.

However, while pedagogical norms have an important impact on the use of the inflected form by our learners, the L2 learner can be influenced by naturalistic exposure, whereby we have seen that study abroad has led to considerable use of the periphrastic form among our learners in Group 2, in line with native speaker norms. Taken together, the findings point to a potential effect for the target language variety in the acquisition of sociolinguistic norms. Whereas Nadasdi et al. report lesser use of the inflected form, reflecting Canadian French sociolinguistic norms, this form dominates among our classroom learners in Group 3, reflecting classroom pedagogic norms. (As we have previously mentioned, we believe the more dominant use of the present in Group 1 to simply reflect the acquisitional difficulty posed by the two other forms, and not necessarily to reflect sociolinguistic or pedagogic norms). Unlike the other groups, our study abroad learners in Group 2, however, show greater development on the periphrastic form, which is used in tandem with the inflected form, reflecting very closely levels of use reported for metropolitan French. The study abroad learners have very clearly been sensitized to such norms, unlike their Canadian immersion counterparts who make far greater use of the periphrastic form to reflect the speech norms of the target language variety to which they have been exposed, as evidenced in the classroom input they have received (see Nadasdi et al. 2003: p. 202). In conclusion, both classroom and naturalistic exposure are seen to differentially impact the forms used in the expression of futurity, while also reflecting an effect of the target language variety. In contrast, other issues such as structural similarity between the periphrastic form in French and English, as well as the L2 learner's general preference for analytical forms as opposed to synthetic forms are not found to be at play in our learner data.

immersion learners were exposed, reflecting its high rate of frequency in native discourse in general. For discussion of the concept of pedagogical norms, see the collection of papers in Gass et al. (2002) and Valdman's extensive work on the topic in terms of the criteria he proposes for the choice of pedagogical norms, among which he places emphasis on the need to expose learners to such variation in terms of their sociolinguistic awareness at least (see, for example, Valdman 1989; 2002). 
Apart from the issue of form, a remaining question underlying this study concerned the issue of how the learners might differ in their use of each future form depending on its prescriptive semantic value, as well as a number of other linguistic factors in context. This question also went to the heart of the issue of how the learners' exposure to the L2 might have a differential impact on their use of each form. As we previously outlined, prescriptive norms, hypothesized to be at play in a pedagogic context, suggest that use of each future form differs primarily according to the semantic values of proximity and distance. In contrast, sociolinguistic norms, as evidenced in a French Canadian context at least, suggest that such semantic restrictions are not at work in real language usage to the extent that prescriptive norms would have us believe. ${ }^{5}$ We can therefore also consider the results in terms of how prescriptive norms, as opposed to sociolinguistic norms, might be evidenced in our learners' use of the future forms, such that their usage better reflects one set of norms than another depending on their context of learning.

In this regard, we have found that the issue of semantic value is at best ambiguous in relation to how the learners use the future forms. As we have seen, the use of all three forms is not as tightly restricted as one might expect based on prescriptive norms, with some overlap in use of the forms across contexts. However, we do nonetheless detect those norms insofar as the present and the periphrastic future are common in proximal contexts, while the inflected form is not found in such contexts at all in Group 2, and the periphrastic form is not found at all in distal contexts in Group 3. However, given the relative overlap in use of the forms across contexts, the impact of prescriptive norms cannot be viewed as greatly outweighing the sociolinguistic norms observed in real language usage, where the forms are increasingly seen to be used interchangeably across semantic contexts. Moreover, as we noted previously, there is a need for caution in interpreting the patterns presented given that, in some cases, they are based on a very small number of tokens.

Apart from the issue of semantic value, other interesting findings concerning the effect of linguistic context on the choice of form relate to the factor of polarity. In this regard, the learners behave differently from native speaker norms, where negation is found to highly favour use of the inflected form. In contrast, our learners demonstrate the opposing tendency, favouring use of the inflected form in affirmative utterances. A final factor considered was that of temporal adverbs. While Group 2 behaves in line with what might be expected from a functionalist perspective, Group 1 does not, with findings less clear-cut in Group 3. Notwithstanding, given the small number

5 We use the term 'prescriptive norms' to refer to the norms presented in traditional grammars, but which may be at odds with the rules found to underlie native use in descriptive studies within a sociolinguistic framework, and which often differ across grammars (see Poplack and Turpin 1999; Poplack and Dion 2009). 
of tokens on which such patterns are based, they remain to be confirmed in future studies.

\section{Conclusion}

Taken together, the findings provide some very preliminary insight into the learners' acquisition of a socio-grammatical variable, which reflect at once the difficulty posed by future reference from a developmental perspective in relation to their grammatical development, as well as in terms of their acquisition of sociolinguistic variation. That difficulty relates to the double-edged sword that is future time reference in target language French, where the learner is confronted with often-times mutually contradictory prescriptive and sociolinguistic norms. Indeed, the difficulty is very clearly seen in our differential findings for our study abroad and classroom learners, where both prescriptive norms and sociolinguistic norms have been suggested as potential reasons for the differential levels of use of each form across the groups. Our findings for future time reference corroborate those of a range of previous investigations of other sociolinguistic variables with regard to the highly beneficial impact of naturalistic exposure on the acquisition of informal variants such as deletion of the negative particle ne, /1/-deletion and use of the $1^{\text {st }}$ person plural subject pronoun on (for an overview, see Mougeon et al. 2010; Howard et al. 2013). The fact, however, that our classroom learners are clearly sensitized to prescriptive norms, as evidenced in their highly frequent use of the synthetic inflected form, as opposed to the simpler, L1-structurally similar, analytic form that is the periphrastic future, would suggest that pedagogic input that also reflects sociolinguistic norms can have a significant effect on learners' sociolinguistic development within a classroom context. It remains for future research to test such a hypothesis!

At a methodological level, the findings also point to some other issues for future research to explore. As we have seen, our spoken production data of over 18 hours yielded a very limited number of tokens of future time contexts, raising questions of the suitability of such data for a richer level of investigation than has been possible here. While we have noted that spoken production data should not necessarily be excluded in the analysis of forms that are not always very frequent in natural discourse, there is a need to complement such data with other data elicitation techniques. These could include other production tasks such as in the written mode, but also more controlled spoken tasks where the learner is required to produce forms in a greater range of future time contexts. While many such techniques forgo the natural spontaneous quality allowed for by the sociolinguistic interview, they do have the advantage of not only providing a larger number of tokens of future time contexts, but also allow the researcher to control for some of the factors that may underlie learner variation in their choice of future time 
marker, such as in relation to the presence of temporal adverbs and the proximity of the event. As we have seen, such factors are extremely difficult to control for in the data on which our study is based, giving rise to a minimal number of tokens in some cells. A final methodological approach might include tapping into the learners' metalinguistic awareness in terms of the reasons underlying their choice of one variant over another. While futurity has been much less the subject of investigation in L2 research on temporality in general, but especially in the case of L2 French, undoubtedly future studies will provide wide-ranging insights.

\section{References}

Ayoun, D. 2013. "The Acquisition of Future Temporality by L2 French Learners." Journal of French Language Studies 23: 1-22.

Bardovi-Harlig, K. 2000. Tense and Aspect in Second Language Acquisition. Form, Meaning and Use. Oxford: Blackwell.

Bardovi-Harlig, K. 2002. "A New Starting Point? Investigating Formulaic Use and Input in Future Expression." Studies in Second Language Acquisition 24: 189-198.

Bardovi-Harlig, K. 2004a. "Monopolizing the Future: How the Go-Future Breaks into Will's Territory and What it Tells Us about SLA." EUROSLA Yearbook 4: 177-201.

Bardovi-Harlig, K. 2004b. "The Emergence of Grammaticalized Future Expression in Longitudinal Production Data." In Form and Meaning in Second Language Acquisition, Ed. M. Overstreet, S. Rott, B. VanPatten and J. Williams. Mahwah, NJ: Erlbaum: 115137.

Bardovi-Harlig, K. 2005. "The Future of Desire: Lexical Futures and Modality in L2 English Future Expression." In Proceedings of the $7^{\text {th }}$ Generative Approaches to Second Language Acquisition Conference (GASLA 2004), Ed. L. Dekydtspotter, R. Sprouse and A. Liljestrand. Somerville, MA: Cascadilla Proceedings Project: 1-12.

Bartning, I. 1997. "L'apprenant dit avancé et son acquisition d'une langue étrangère : Tour d'horizon et esquisse de la variété avancée. "Acquisition et interaction en langue étrangère 9: 9-50.

Bartning, I. 2009. "The Advanced Learner 10 Years On.” In The Advanced Learner Variety. The Case of French, Ed. E. Labeau and F. Myles. Oxford: Peter Lang: 11-40.

Bayley, R. 1996. "Competing Constraints on Variation in the Speech of Adult Chinese Learners of English." In Second Language Acquisition and Linguistic Variation, R. Bayley and D. Preston. Amsterdam / Philadelphia: Benjamins: 97-120.

Beeching, K. 2002. Gender, Politeness and Pragmatic Particles in French. Amsterdam / Philadelphia: Benjamins.

Blanche-Benveniste, C. 1990. Le français parlé : études grammaticales. Paris: Éditions du CNRS.

Blanche-Benveniste, C. and Jeanjean, C. 1987. Le français parlé : transcription et édition. Paris: Didier.

Blondeau, H. 2006. "La trajectoire de l'emploi du futur chez une cohorte de Montréalais francophones entre 1971 et 1995. " Canadian Journal of Applied Linguistics 9: 73-98.

Carruthers, J. 1999. "A Problem in Sociolinguistic Methodology: Investigating a Rare Syntactic Form.” Journal of French Language Studies 9: 1-24. 
Chevalier, G. 1996. "L'emploi des formes du futur dans le parler du sud-est du NouveauBrunswick. "In Les Acadiens et leur(s) langue(s) : quand le français est minoritaire, Ed. L. Dubois and A. Boudreau. Moncton: Université de Moncton - Centre de recherche en linguistique appliquée: 75-89.

Confais, J.-P. 1995. Temps mode aspect: Les approches des morphèmes verbaux et leurs problèmes à l'exemple du français et de l'allemand. Toulouse: Presses Universitaires du Mirail.

Deshaies, D. and Laforge, E. 1981. "Le futur simple et le futur proche dans le français parlé dans la ville de Québec. "Langues et linguistique 7: 23-37.

Dewaele, J.-M. 2004. "The Acquisition of Sociolinguistic Competence in French as a Foreign Language: An Overview." Journal of French Language Studies 14: 301-319.

Dietrich, R., Klein, W. and Noyau, C. 1995. The Acquisition of Temporality in a Second Language. Amsterdam / Philadelphia: Benjamins.

Emirkanian, L. and Sankoff, D. 1985. "Le futur simple et le futur périphrastique dans le français parlé. "In Les tendances dynamiques du français parlé à Montréal, Ed. M. Lemieux and H. Cedergren. Montreal: Office de la langue française: 189-204.

Evans Wagner, S. and Sankoff, G. 2011. "Age-Grading in the Montréal French Inflected Future." Language Variation and Change 23: 275-313.

Fleischman, S. 1982. The Future in Thought and Language: Diachronic Evidence from Romance. Cambridge: Cambridge University Press.

Gass, S., Bardovi-Harlig, K., Sieloff-Magnan, S. and Walz, J. 2002. Pedagogical Norms for Second and Foreign Language Learning and Teaching. Amsterdam / Philadelphia: Benjamins.

Giacalone Ramat, A. 1992. "Grammaticalization Processes in the Area of Temporal and Modal Relations." Studies in Second Language Acquisition 14: 297-322.

Gougenheim, G. 1971. Études sur les périphrases verbales de la langue française. Paris: A-G Nizet.

Harley, B. 1992. "Patterns of Second Language Development in French Immersion." Journal of French Language Studies $2: 159-183$.

Howard, M. 2005. "Second Language Acquisition in a Study Abroad context: A Comparative Investigation of the Effects of Study Abroad and Foreign Language Instruction on the L2 Learner's Grammatical Development." In Investigations in Instructed Second Language Acquisition, Ed. A. Housen and M. Pierrard. Berlin / New York: Mouton deGruyter: 495-530.

Howard, M. 2006a. "The Expression of Number and Person Through Verb Morphology in French Interlanguage." International Review of Applied Linguistics 44: 1-22.

Howard, M. 2006b. "Variation in Advanced French Interlanguage: A Comparison of Three (Socio)linguistic Variables." Canadian Modern Language Review 62: 379-400.

Howard, M. 2012. "The Advanced Learner's Sociolinguistic Profile: On Issues of Individual Differences, L2 Exposure Conditions and Type of Sociolinguistic Variable." The Modern Language Journal 96: 20-33.

Howard, M., Mougeon, R. and Dewaele, J.-M. (2013). "Sociolinguistics and Second Language Acquisition." In Oxford Handbook of Sociolinguistics, Ed. R. Bayley, R. Cameron and C. Lucas. Oxford: Oxford University Press: 340-359.

Jeanjean, C. 1988. «Le futur simple et le futur périphrastique en français parlé. » In Grammaire et histoire de la grammaire : hommage à la mémoire de Jean Stefanini, Ed. C. BlancheBenveniste, A. Cherval and M. Gross. Aix-en-Provence: Publications de l'Université de Provence: 235-257.

Kihlstedt, M. 1998. La référence au passé dans le dialogue. Étude de l'acquisition de la temporalité chez des apprenants dits avancés de français. Stockholm: Akademitryk.

\section{Arborescences}

Revue d'études françaises

ISSN: 1925-5357 
King, R. and Nadasdi, T. 2003. "Back to the Future in Canadian French." Journal of French Language Studies 3: 323-337.

Labeau, E. 2005. Beyond the Aspect Hypothesis. Tense-Aspect Development in Advanced L2 French. Oxford: Peter Lang.

Labov, W. 1984. "Field Methods of the Project on Linguistic Change and Variation." In Language in Use: Readings in Sociolinguistics, Ed. J. Baugh and W. Scherzer. Englewood Cliffs, NJ: Prentice Hall: 28-53.

Li, P. and Shirai, Y. 2000. Acquisition of Lexical and Grammatical Aspect. Berlin / New York: Mouton deGruyter.

McDonough, K. and Trofimovich, P. 2009. Using Priming Methods in Second Language Research. Abingdon: Routledge.

Mougeon, R., Rehner, K. and Nadasdi, T. 2010. The Sociolinguistic Competence of Immersion Students. Bristol / Toronto: Multilingual Matters.

Moses, J. 2002. The Development of Future Expression in English-Speaking Learners of French. Doctoral Thesis, Indiana University.

Nadasdi, T., Mougeon, R. and Rehner, K. 2003. «Emploi du futur dans le français parlé des élèves d'immersion française. " Journal of French Language Studies 13: 195-219.

Poplack, S. and Dion, N. 2009. "Prescription versus Praxis: The Evolution of Future Temporal Reference in French." Language 85: 557-587.

Poplack, S. and Turpin, D. 1999. "Does the futur Have a Future in (Canadian) French?" Probus 11: 133-164.

Rehner, K., Mougeon, R. and Nadasdi, T. 2003. "The Learning of Sociostylistic Variation by Advanced FSL Learners: The Case of nous versus on in Immersion French." Studies in Second Language Acquisition 25: 127-157.

Roberts, N. 2012. "Future Temporal Reference in Hexagonal French." University of Pennsylvania Working Papers in Linguistics 18: 97-106.

Salaberry, R. and Shirai, Y. 2002. The L2 Acquisition of Tense-Aspect Morphology. Amsterdam / Philadelphia: Benjamins.

Schlyter, S. 1990. "The Acquisition of French Temporal Morphemes in Adults and Bilingual Children." In La temporalità nell'acquisizione di lingue seconde, Ed. G. Bernini and A. Giacalone Ramat. Milan: Franco Angeli: 293-308.

Sundell, L.-G. 1991. Le temps futur en français moderne. Uppsala: Textgruppen i Uppsala AB.

Valdman, A. 1989. "The Elaboration of Pedagogical Norms." In Variation in Second Language Acquisition: Discursive and Pragmatics, Ed. S. Gass, C. Madden, D. Preston and L. Selinker. Clevedon: Multilingual Matters: 15-34.

Valdman, A. 2002. "The Acquisition of Sociostylistic and Sociopragmatic Variation by Instructed Second Language Learners: The Elaboration of Pedagogic Norms." In The Sociolinguistics of Foreign Language Classrooms: Contributions of the Native, Near-Native and the Non-Native Speaker, Ed. C. Blyth. Boston: Heinle: 57-78.

Vet, C. 1993. "Conditions d'emploi et interprétation des temps futurs du français. "Verbum 4: 71-84.

Wales, M. 2002. "The Relative Frequency of the Synthetic and Composite Futures in the Newspaper Ouest France and Some Observations on Distribution." Journal of French Language Studies 12: 73-93.

Wiberg, E. 2002. "Information Structure in Dialogic Future Plans. A Study of Italian Native Speakers and Swedish Pre-Advanced and Advanced Learners of Italian." In The L2 Acquisition of Tense-Aspect Morphology, Ed. R. Salaberry and Y. Shirai. Amsterdam / Philadelphia: Benjamins: 285-322.

\section{Arborescences}

Revue d'études françaises

ISSN: 1925-5357 
Wolfram, W. 1985. "Variability in Tense Marking: A Case for the Obvious." Language Learning 35: 229-253.

Zimmer, D. 1994. "Ça va tu marcher, ça marchera tu pas, je le sais pas. Le futur simple et le futur périphrastique dans le français parlé à Montréal. " Langues et linguistique 20: 213225. 


\section{Appendix 1}

List of verbs marked for futurity in the L2 learner corpus

\begin{tabular}{|cl|}
\hline \multirow{2}{*}{ Group } & \multicolumn{1}{c|}{ Verb form } \\
\cline { 2 - 3 } & \multicolumn{1}{c|}{ Inflected future } \\
\hline Group 1 & aller, améliorer, avoir, être, finir \\
\hline Group 2 & $\begin{array}{l}\text { aider, avoir, chercher, devoir, } \\
\text { être, faire, suivre }\end{array}$ \\
\hline & $\begin{array}{l}\text { acheter, aimer, avoir, changer, blesser, faire, voir } \\
\text { enseigner, essayer, être, faire, } \\
\text { gagner, marcher, pouvoir, } \\
\text { grendre, rentrer, traiter, venir }\end{array}$ \\
\hline
\end{tabular}

